\title{
INTERVIEW WITH ARTHUR AND MARGARET PALMER
}

\section{“THE LESSONS WE LEARN FROM LIVING ON KARST CAN BE EXTENDED FAR INTO OTHER GEOLOGIC REGIONS”}

\author{
conducted by Ivo LUCIĆ
}

We are glad to publish another Interview conducted by Ivo Lucić. It was made in 2010, then sent to the editorial office in 2012, but lost in the hyperspace and found again. Luckily, the interview is just as interesting to read as at the time, it was made. We apologize to the interviewees and interviewer for the delay. The work of Art and Peggy Palmer has been an inspiration to many of us. What follows is just another confirmation of their devotion to karst \& caves end each other and their sincere modesty.

Editor

\section{PERSONAL AND BEGINNINGS}

Arthur and Margaret Palmer are well known for their karst research, mainly in North America. Arthur (Art) is Professor Emeritus of Hydrogeology at the State University of New York, Oneonta, NY, and Margaret (Peggy) is a consulting geologist with a specialty in carbonate petrology. Except where noted otherwise, the answers below represent their combined views.

\section{How did you meet?}

Art: Appropriately, we met on a karst field trip in 1964, when I was a PhD student at Indiana University and Peggy was an undergraduate geology major. We were married in 1966 and have worked closely together in karst ever since.

Peggy: Art later invited me on a cave trip along with some of his friends, and I was thrilled to meet such wonderful and interesting people. I continued to go with

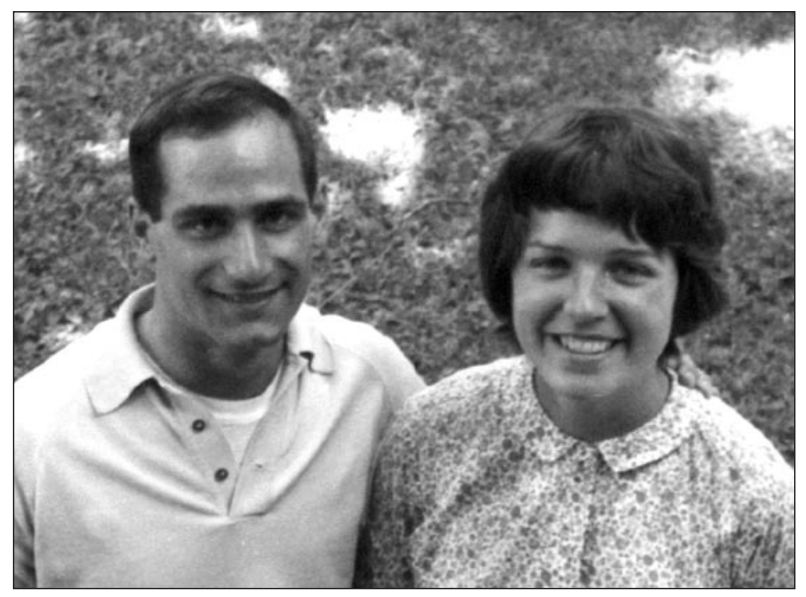

Art and Peggy Palmer soon after their wedding in 1966. (Photo: Tom Hall.) them to help map a long and wet cave (Blue Spring Cave, at that time one of the 10 longest known caves in the world). It was exhausting, but I enjoyed learning to explore and survey, and to be part of a dedicated group.

What attracted you to karst? What influenced you to continue in this field for your entire lives?

Art: I've always loved exploration and the unknown, from the time I was a child in Massachusetts. In my teen years, it became clear that cave exploration offered the best outlet for this goal. I also had an interest in spatial relationships and mapping, and again caves offered an ideal outlet. An unexpected bonus was that caving offered physical activity and the close companionship of others. Geology and hydrology were the sciences I enjoyed most, and as I studied them in college my interests in caving broadened to include the genesis of caves and karst. In graduate school at Indiana University I was

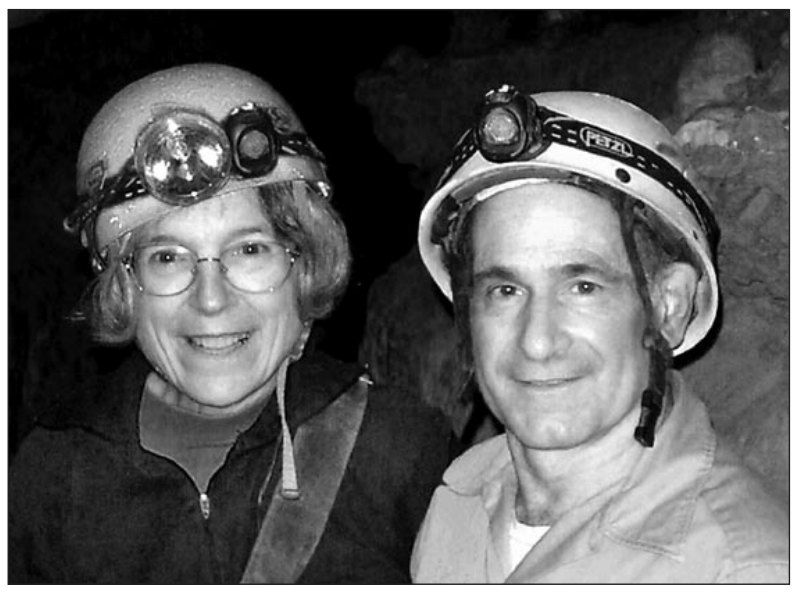

Teaching a Karst Geology course at Mammoth Cave for Western Kentucky University, 2007. (Photo: E. Scott Bair.) 
already an experienced cave explorer and mapper, but I had decided to pursue traditional hydrology and to keep speleology as merely a hobby. Fortunately my advisor, Allen Agnew, had no difficulty convincing me that I should concentrate on karst hydrology. It was Dick Powell of the Indiana Geological Survey, an extraordinary field geologist, who had the greatest influence on my growth as a karst scientist. And most importantly, Peggy has been a companion and colleague for more than 40 years, and her interest has grown along with my own.

Peggy: In college I found that a concentration in geology fit my interests best. Regarding caves, at first my interest was mainly social, but the thrill of exploring and mapping a large cave system gradually took hold. I also developed a project to study Indiana's karst landscapes and geologic structure. In the master's program at the State University of New York I became very attached to carbonate petrology and have been involved in that field ever since. Art and I have been very fortunate to have complementary interests that overlap in a positive way, rather than competitively. More than just a married couple, we've always been the best of friends. During nearly half a century we've somehow retained much of our health and physical ability and still do vigorous field work for several months each year.

How do you view karst science as a whole? Do you accept term karstology? Do you consider yourselves to be karstologists?

To us, karstology includes all aspects of dissolution of rock to produce features of geomorphic and hydrologic importance. It involves most of all the geologic, hydrologic, and chemical processes and the geologic framework in which they operate. Finally there are the human aspects of karst: exploration, mapping, water supply, engineering, and economic geology (e.g. petroleum and ores). Karstology involves all of these, and probably other related topics as well. Yes, we consider ourselves karstologists (i.e., karst scientists).
What was the perception of karst and karstology in the USA when you were at the doorstep of this field? How did the world of karstology seem to you at that time? How many karst centers were there, and what was their main purpose?

Art: When I became involved in karst science in the early 1960s, my first creative act was a college honors thesis that examined the origin of a cave system in the Northeastern USA. This caused me to delve into the literature and to communicate with the established scientists in the field. At that time, the field was very strongly geomorphic, with emphasis on the origin of caves and related features. Studies were mainly based on field observation, and they relied on chemistry and hydrology only in the most rudimentary ways. For example, the debate as to whether most caves were formed above, at, or below the water table still persisted, but was gradually being resolved. Since about the beginning of the $20^{\text {th }}$ century many competent studies of karst landscape had been made, particularly in the large karst areas of the east-central USA and Appalachian Mountains; but they were rather local in scope and did not draw as much attention as the more hypothetical and controversial studies of cave origin.

At that time there were no real centers of scientific karst studies in the USA (or in all of North America). Organizations dedicated to karst at that time included the National Speleological Society (NSS), which despite a very strong emphasis on caves, contained a number of very prominent scientists who furthered the scientific aspects of the field. They included George Moore and William Davies (both of the U.S. Geological Survey). On the academic front, Will White at the Pennsylvania State University, and Derek Ford at McMaster University (Canada) where the primary leaders in this field. George Moore organized several NSS symposia on important topics in karst, such as the origin of caves, which drew many budding scientists to the field. The proceedings were published in the NSS Bulletin, the scientific journal

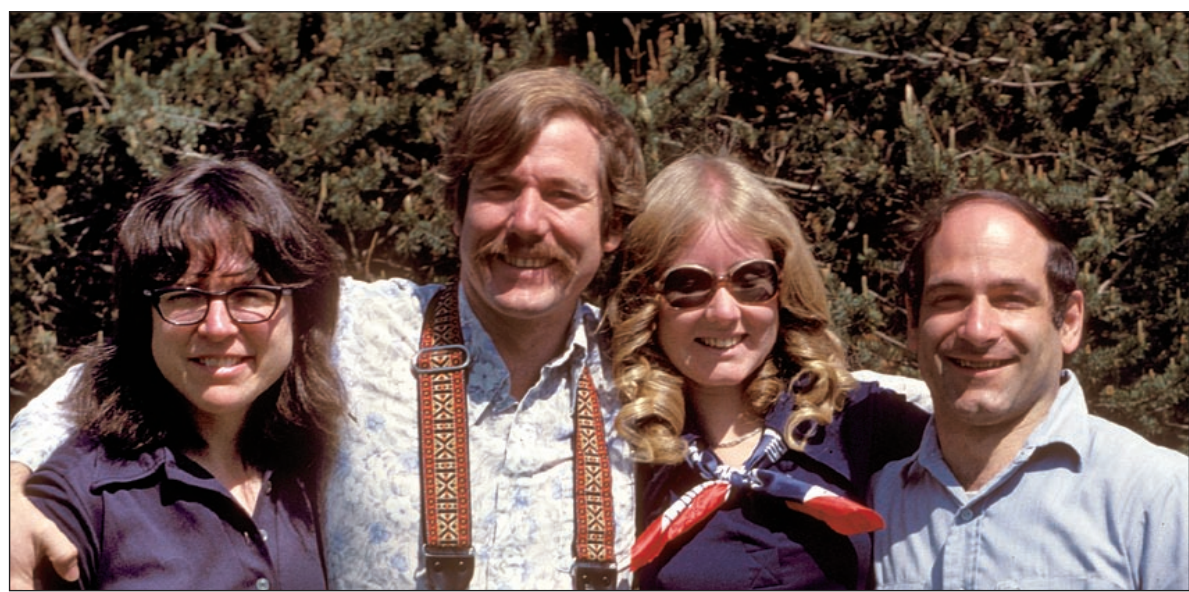

Peggy and Art Palmer, flanking John and Joan Mylroie, who are now well-known specialists in coastal karst (1979). 
of the society (now the Journal of Cave and Karst Studies). These symposia gave a valuable boost to karst science in America. Meanwhile, smaller groups such as the Cave Research Associates (western USA, especially California) progressed on their own, often in some secrecy to protect caves from unwarranted traffic. They also included dedicated scientists, most of whom were also NSS members, who published articles on cave science for a couple of decades in their newsletter Cave Notes.

\section{KARSTOLOGY DEVELOPMENT}

How well developed were research conditions at that time, and, as karstologists, how did you feel in comparison with colleagues in others disciplines?

American karst research in the 1960s was gaining firmer ground after several decades of scattered and poorly integrated work. These advances were mainly through the efforts of NSS scientists. The two of us were cordially welcomed by the scientific community on the basis of our studies of cave geology and morphology, but at that time, karst was not highly regarded by scientists in other fields.

Art: My specialty of hydrogeology was undergoing tremendous growth at that time, and as a professor in that field at the State University of New York I was able to train hundreds of students who specialized in it. I focused on traditional groundwater hydraulics, with karst inserted in its proper place, but given no more than its appropriate share of attention. However, my publications were almost entirely in karst, and so among other scientists I became known mainly as a karst hydrologist. Until quite recently, traditional groundwater hydrologists regarded karst as a pseudo-science dominated by sport cavers. This view still persists in some circles. But the complexity of water flow in karst, and its interaction with chemical kinetics, far surpass the scope of traditional groundwater studies. The failure to recognize this difference has led to many disasters such as fatal groundwater contamination and structural collapse. Life is much easier for karst scientists today.

Peggy: Most of my time was spent in the laboratory, and with few publications and presentations, I had relatively little exposure to others in the scientific community. My later work on paleokarst has received a fair amount of attention, mainly from by petroleum geologists. Scientists in other branches of geology, such as sedimentology and stratigraphy, seem very receptive to new ideas in karst.

Which phases have you observed in the development of karst science, and what do you consider to be the major milestones?

While we have been involved in the field, the development of North American karst science can be briefly summarized as follows: 1960s: Resolving of the basic questions regarding cave origin. Karst science expanded into wider fields, such as biology, archeology, hydrology, and geochemistry. 1970s - 1980s: Assimilation of hydraulics and chemical kinetics into karst science; development of dating techniques for cave deposits; broadening of horizons to include coastal karst and hydrogen sulfide speleogenesis. Digital modeling of karst, later superseded by European work. 1990s: Integration of karst-related sciences, especially geology, hydrology, biology, and paleoclimatology. Accelerated recognition of the importance of microbial processes in karst. Establishment of the Karst Waters Institute, which hosts interdisciplinary meetings that bring together scientists from many diverse fields. Recognition of chemoautotrophy in subsurface environments. Application of cave data to Pleistocene climatic variations. Growing knowledge of phylogeny and evolutionary patterns of subsurface biota helps to interpret the age of karst drainage systems. Since 2000: National attention has been drawn to karst as an important field. Karst sessions have grown rapidly at major scientific meetings (e.g., Geological Society of America). Establishment of the National Cave and Karst Research Institute by U.S. Congress. University karst programs have multiplied.

Can you compare the history of karst studies in the USA with those in others parts of world?

Early karst studies in the USA were heavily focused on cave origin, more than on integrating the various aspects of karst science. Elsewhere, scientists tended to integrate karst with surface geomorphology (e.g., Cvijić). Broad karst studies were relatively modest in America, but cave studies were probably more advanced. Some very well-known geologists, such as William Morris Davis, J Harlen Bretz, Allyn Swinnerton, and Clyde Malott, wrote lengthy papers on cave origin. But they tended to disagree with one another, and their work was not grounded in chemistry and hydraulics. As a result there was a general feeling that cave studies (and karst science in general) were "soft" sciences of less importance than, for example, traditional groundwater hydrology. Only in the past few decades have the karst sciences been accepted on the basis of their rigorous approach and environmental applications. In other countries it seems that karst has always been held in high regard.

It seems from our vantage point that karst studies in most other countries, especially in Europe, have had a much longer and more coherent history. The central topic was traditional geomorphology (i.e., that of Davis and Penck), which formed a solid framework for other aspects of karst science, such as groundwater hydrology. Caves and surface karst were treated as a united topic. 
An appreciation for subsurface hydraulics and chemical processes in karst was achieved in Europe long before it was in America. For example, the advanced nature of geochemical studies in Eastern Europe in the mid-20 $0^{\text {th }}$ century has only recently become evident to us in the West. Particularly in Europe and China, karst has had a more direct impact on human history and seems an integral part of the culture. Governmental support for karst studies in America has historically been weaker than elsewhere, at least until recently.

For the past two decades the most significant advance in karst science has been multi-national collaboration. The Internet, despite its flaws, has demolished most of the barriers to international communication. Karst researchers everywhere now realize the immense contribution, both contemporary and historical, by their peers in other parts of the world.

How does karst science relate to traditional and modern scientific knowledge in the USA and North America?

Karst is quickly being integrated into many other sciences, most particularly groundwater hydrology, engineering, sedimentology-stratigraphy, paleoclimatology, and economic geology. Dating of cave deposits is now at the forefront of geomorphic interpretation and is beginning to overturn many old ideas of landscape development, for example the rates at which it takes place. Interdisciplinary meetings have drawn specialists together from many different disciplines. For example, the first symposium hosted by the Karst Waters Institute (Colorado Springs, Colorado, 1994) was on the topic of karst geomicrobiology and redox geochemistry. It drew contributions from some of the most prominent geologists and biologists, and even from the space agency NASA. Since then, the field of karst microbiology has blossomed. Other meetings have dealt with petroleum reservoirs, aquifer studies, groundwater modeling, climatology, and geochemistry of karst.

\section{KARSTOLOGY TODAY}

What is karstology today, a century after it was established? The prevailing view is geomorphologic, with an emphasis on soluble rocks and underground flow; but there are also different approaches, like that of Daoxian (1988), who sees karst as a complex, dynamic and interactive system that incorporates landforms with life, energy, water, gases, soils, and bedrock. Where do your views fall into this spectrum?

All of these aspects are significant, both theoreti$\mathrm{cal}$ and applied. Cultural aspects, land-use management, and environmental protection are of growing concern in karst. In this aspect, the USA is perhaps more advanced than most other parts of the world. The National Cave and Karst Research Institute was established partly with these goals in mind. Many agencies of state and national government (e.g. U.S. Environmental Protection Agency) consider the environmental problems in karst to be of prime importance.

Can you describe your own approach to karstology? Objectively, and overcoming modesty, what do you consider your best contributions to karst sciences?

Art: My approach is to combine the detailed field mapping and laboratory analyses with the functional relationships of hydraulics and chemistry, so that each aspect can be made to support the other. I think my main achievements in karst include: (1) Interpretation of cave origin and morphology, particularly by explaining the development of cave patterns. This is based on detailed geologic mapping and the application of hydraulics and chemical kinetics. (2) First successful digital modeling of caves and cave patterns (1981-1991) using a combination of hydraulics and chemical kinetics, to provide the functional relationships between discharge, gradient, chemistry, and temperature and the rate and pattern of cave development. Since 1990, more sophisticated multidimensional modeling has been done by European scientists such as Wolfgang Dreybrodt, although the basic functional relationships still seem to apply. (3) Guiding many students in hydrology and in karst studies since the late 1960s.

Together we have interpreted the geology, cave origin, and karst in several significant areas, especially the Mammoth Cave region, Guadalupe Mountains of New Mexico, and Black Hills of South Dakota. With great help from Peggy's laboratory skills (microscopy, carbonate mineralogy and petrology, X-ray diffraction, etc.) we have, together, gained a substantial understanding of paleokarst, particularly the complex mid-Carboniferous events in the American West.

Peggy: Because there are two of us, we've been able to stay rather independent in our research. This has had both good and bad consequences. We started several large projects in the national parks and have collected many samples, mainly bedrock, weathering products, and carbonate cements, which relate to the interpretation of caves, contemporary karst, and paleokarst. Decades of lab time have gone into analyzing these samples. To me, that's where the real adventure begins. We continually re-examine our interpretations, which is a hidden benefit (or curse) of long-range projects that are not driven by grants. Now the only difficulty is to finish these projects in our lifetime.

Art: I can't overstate Peggy's skill at carbonate petrology using basic light microscopy. I look through the microscope and see lots of pretty colors arranged like a puzzle. She glances at the same object and seems able to 
describe its entire geologic history. In the future she will be senior author of many of our publications.

How would you categorize the contradictory systematic positions of karstology as a science? It appears that only one article has supplied detail on that topic (Panoš 1995). He sees it as "an independent integrated scientific system of individual branches that take up complex studies of regions underlain with rock being variably soluble by water". It seems that workers in other fields such as volcanology or oceanography have done more with this topic.

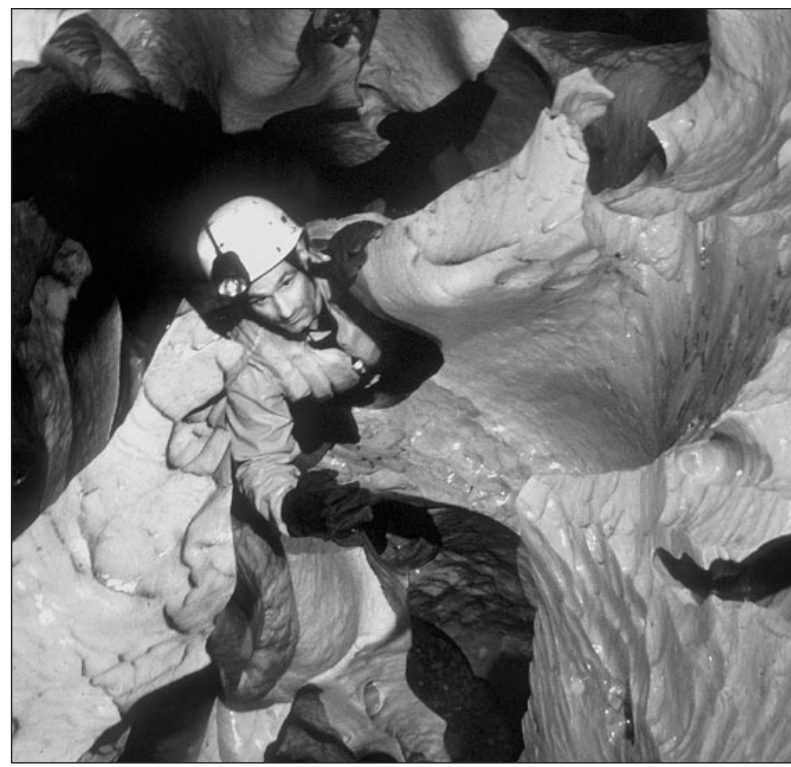

Art Palmer in Cueva Zumbo, Puerto Rico, a tributary of the extensive Río Encantado System, 1988 (Photo: Kevin Downey).

Most karst scientists recognize the range and limits of their field without bothering to define it in words. But it's an important topic to consider. For example, here is an aspect of karst that is rarely expressed: The basic principles of hydrology, geochemistry, geomorphology, and land-use management in karst extend far beyond the limits of highly soluble rocks (carbonates and evaporites). All rocks are soluble to some extent, and even where dissolution is negligible, the manner by which water moves through bedrock of any kind can be vastly clarified by an understanding of cave patterns and their development. The same fissures and pores that guide cave-forming water are also present in non-karst aquifers, so caves can tell us a great deal about contaminant transport in all aquifers. Although the application of karst to human endeavors is complex, it is easily recognized - for example when one's house disappears into a karst depression. And yet it is difficult to draw clear boundaries around the phenomenon of karst, and the lessons we learn from living on karst can be extended far into other geologic regions.
What are the most interesting and important topics in karstology today? What is its biggest problem?

Our previous statements have touched on this subject. A few of the major topics include: (1) Integration of karst science with other disciplines of the earth sciences, as well as with biology, planetary science, archeology, and many others. For example, the vast influence of microbial processes on geology are nowhere more easily demonstrated than in karst. (2) Practical application of karst principles to economic and environmental issues, such as land-use management, groundwater contamination, and paleoclimatology (as a tool in quantifying climate change). (3) Resolution of conflicts between indirect field methods (e.g., digital modeling and remote sensing, geophysical exploration) and the tangible results of direct observation (e.g., well cores, oilfield production, dye traces to confirm dispersion of contaminants).

Topics of interest in karst science include: (1) Distinction between epigenetic and hypogenetic cave origin. (2) Practical application of speleogenetic models, such as leakage beneath dams, emplacement of ore bodies, and generation of subsurface porosity (e.g., in petroleum fields). (3) Integration of cave studies with regional geomorphic and tectonic evolution. This topic extends in both directions. The initial interpretation of a cave system is aided by an understanding of its regional context; but with time, the cave pattern and contents (e.g., sediments) can provide even more information about the surrounding region. Examples include clarification of the drainage history of the eastern USA from sediment dating and passage levels in Mammoth Cave, and dating of tectonic events from dating of sulfuric-acid-generated alunite in caves of the Guadalupe Mountains, New Mexico.

Art: The biggest problem today is the perception of karstology as a science. A century ago the study of karst was highly regarded. In the mid-20th century the field diverged from traditional hydrogeology because of its growing emphasis on caves, which are foreign territory for most scientists. Meanwhile, hydrogeology became infused with the idea that groundwater problems are best solved by the application of higher math, despite the fact that it is appropriate only for idealized porous media. Traditional groundwater hydrologists then, and even today, have regarded the messy world of karst as almost a pseudo-science. Look at any textbook on groundwater hydrology and you will find only the most basic ideas about karst, with little attempt to understand karst groundwater flow. Hidden is the fact that mathematics alone is poorly suited to the heterogeneous character of even the simplest aquifers. Digital models have the same limitations. Attempting to apply these tools to karst, or any kind of bedrock aquifer, is like bringing a Stradivari violin to a barn dance. 


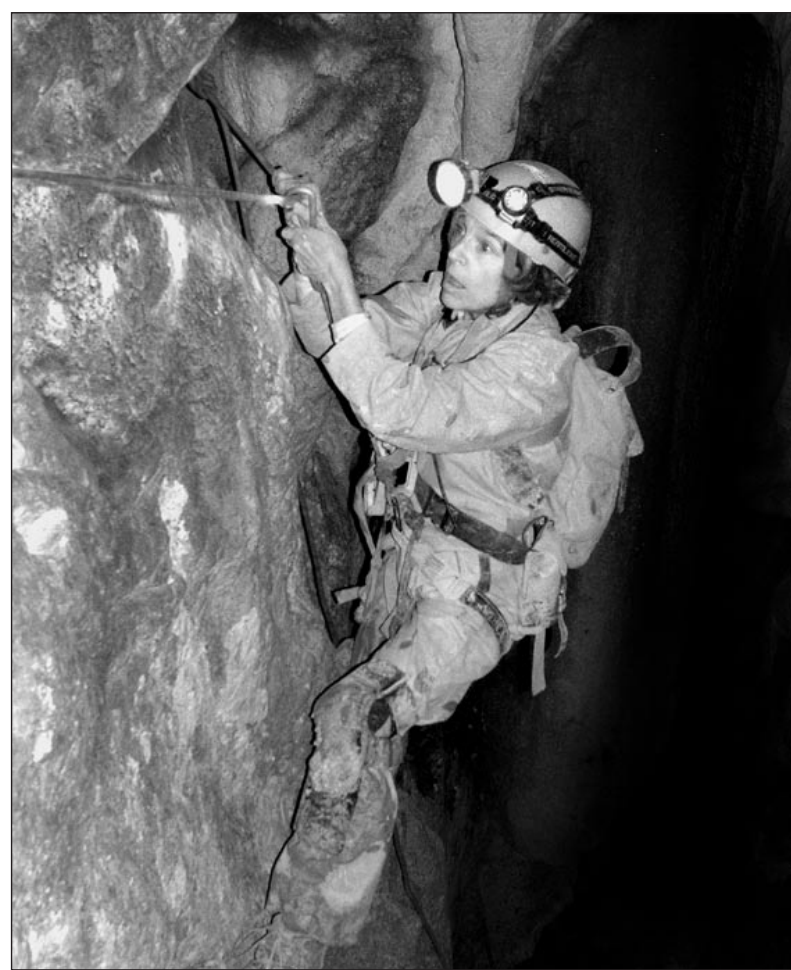

Peggy Palmer in the Faggeto Tondo Cave, Italy (2005), on a trip led by Marco Menichetti, University of Urbino. This is an alpine cave, but thick deposits of secondary gypsum show that much, or all, of its origin was by sulfuric acid (Photo: Art Palmer).

In contrast, karst hydrologists face the task of combining traditional groundwater science with open-channel and conduit hydraulics, geochemical equilibria and kinetics, geomorphic evolution, and detailed geologic mapping. Isn't this the more challenging field?

Karstology faces the problem of embracing a more holistic picture, and to synthesize the work of many different disciplines. Karstology is often turned to the natural sciences, in many cases exclusively, and has omitted the social and humanistic aspects. I know personally many speleologists, geologists, geomorphologists and hydrogeologists who have never considered integrating other disciplines to achieve a more complex picture of karst. How can we achieve a wider picture of karst and karstology?

This will probably always be a problem. In the USA this problem is probably not as great as elsewhere because there is so much emphasis on environmental issues and preservation of natural sites. Many American karst regions are highly populated (e.g., Florida, eastcentral states, Appalachian Mountains, etc.), and such topics as sinkhole subsidence are well known. The US Environmental Protection Agency and the US Geological Survey, among other federal and state agencies, have many karst specialists on their staffs, so human impacts on karst, and impacts of karst on humans, are constantly monitored. This activity is not as widespread as one might wish, but it is far better than in the past.

Within karst science, there is now a strong convergence of interests between geologists, biologists, chemists, and others. Perhaps the most productive alliance is between geologists and microbiologists, especially in the field of sulfuric acid karst. Even the remote field of planetary geology is looking for guidance from terrestrial karst studies. Karst is still poorly represented in most university programs, but at the professional level the walls around karst science are beginning to crumble.

What is the social status of karstology as science? Do karstologists get awards and honors as others do? What are your experiences?

The status of karst scientists has improved greatly in the past quarter century, but there is still a serious deficiency in karst education. University courses and textbooks rarely give more than a quick overview of karst, and there is almost no attempt to integrate the topic with groundwater hydrology, geochemistry, and engineering. Learning to apply karst principles to other fields is almost always left to individuals.

The number of honors and awards to karst scientists will always be less than in major fields such as physics, but they are gaining in number and quality. For example, there will never be a Nobel Prize in karst, but neither is there an award for geology. One has to accept global priorities.

In North America there have been several highprofile awards to karst scientists by major scientific organizations. In 2004, both William B. White (USA) and Derek C. Ford (Canada) received the Distinguished Career Award from the Quaternary Geology and Geomorphology Division of the Geological Society of America, and a tribute volume of papers in karst was published by GSA in 2006 (Special Paper 404). At least two past GSA presidents have been karst scientists, as is the present Chairman of the Board.

Art: I have received several awards directly or indirectly for my work in karst. Most have been "internal awards" granted by karst societies such as NSS and KWI. But in 1994 I received the Kirk Bryan Award for advances in geomorphology from the Geological Society of America, for a paper in the GSA Bulletin on Origin and Morphology of Limestone Caves (1991). This paper also received nominations for a similar award in hydrology. My advancement through the State University of New York (SUNY) was greatly facilitated by my standing as a karst researcher, as much as by my position as Director of the Water Resources Program and service to the community regarding water supply and quality. In particular, I received a SUNY Distinguished Teaching Professorship 
(a university-wide promotion beyond full professor) and the SUNY Award for Distinguished Research.

Peggy: Although my professional profile is well below the radar, I have been granted Honorary Membership in the NSS (1983) and a KWI achievement award (2003). These have been granted internally by the karst community, and I am grateful for their recognition.

What is your opinion on establishing a karstology association?

In general we favor strengthening present organizations rather than establishing new ones. Perhaps the UIS is already the appropriate organization. Of course in name it is focused mainly on caves, but its true function covers most aspects of karst. If other activities are needed, it seems appropriate to address them with new sections of the UIS. Today there are so many national and international scientific meetings that it is impossible to participate in more than a small fraction of them. Adding a new organization would add still more complexity to an already-crowded field.

Which regional centers seem to you most productive and most forward-looking in karstology?

The most productive and forward-looking regional center in our experience is the Slovenian Karst Institute, especially because of its annual "karst schools" with their international participation. Many other karst institutes throughout the world have achieved great success. They include national centers in China, Romania, Croatia, Hungary, Switzerland, and France, as well as at universities. Most of these centers are highly interdisciplinary. We do not attempt a complete list for fear of omitting some.

\section{NORTH AMERICAN KARST}

Would you please outline the main features, values, research, environmental problems and visions of karst in the USA and North America?

Karst in the USA and elsewhere in North America is highly varied, from sub-tropical to alpine and arctic, and to arid-zone deserts. Its largest karst areas are low-relief karst plateaus in the east-central USA and Florida. Cave origin of all kinds has been recognized, and some of the earliest and most detailed studies of sulfuric acid speleogenesis have been performed in the western USA. Research has spread across nearly every aspect of karst, with most emphasis on environmental problems, water supply and quality, economic geology, paleokarst, and microbial studies. Environmental problems include groundwater contamination, ground instability, and sinkhole collapse, and white-nose syndrome, a largely fatal disease among bats that is spreading through the continent, mainly by bat-to-bat communication.
There are several karst centers and organizations in the USA. The Karst Waters Institute and National Cave and Karst Research Institute offer highly interdisciplinary scientific programs. NCRI is building a new research facility in Carlsbad, New Mexico, the only one of its kind in America. The Cave Research Foundation has a large field station on the border of Mammoth Cave National Park in Kentucky, which hosts a constant stream of visiting scientists and cavers as well as monthly CRF cavemapping expeditions. The National Speleological Society holds annual meetings that include many scientific sessions, although most of the NSS activities center on nonscientific aspects of speleology. Several of these organizations collaborate with government agencies and private consulting firms to offer a biennial "Sinkhole Conference" that deals with environmental and engineering problems in karst. Visions for the future include expansion of NCRI and development of digitized data-bases of karst information.

A growing number of North American universities are prominent in karst research. With the retirement of Drs. Will White and Derek Ford, the two most productive academic programs in karst have largely disappeared; but others have sprouted in their place, many of which are led by graduates of Drs. White and Ford, or even by "grand-graduates" trained by the original graduates. Few, if any, North American universities offer degrees specifically in karst, but many provide course work, field studies, and advisement in karst. Students of karst now have a great variety of choices as to where to pursue graduate-level studies. Some of the leading karst programs are located at Western Kentucky University (e.g., Center for Cave and Karst Studies, which offers a summer field program at Mammoth Cave), New Mexico Institute of Mining and Technology, University of South Florida, Mississippi State University, University of Texas, University of Akron (Ohio), Ohio University, and University of West Virginia, among others. (Art is now retired but serves as advisor to students at some of these institutions and as instructor of Karst Geology at Western Kentucky University).

\section{DINARIC KARST}

The Dinaric karst is recognized as the birthplace of karstology. How do you perceive it? With which centers and colleagues from the Dinaric karst have you had productive and uninterrupted cooperation?

The Dinaric karst is of great interest to every serious karst researcher. Most of the international karst terminology comes from that region. It is certainly one of the most important karst areas of the world in terms of the scale and variety of features. To most Westerners the Dinaric karst is the true home of karst. This viewpoint 
of course differs as one travels eastward. The karst of Southeast Asia is more extensive and has greater intensity of karst features, and there is little question that it is at least as important on a world-wide scale. But many examples of karst (e.g., sulfuric acid karst and evaporite karst) are not well developed in either the Dinaric karst or in Southeast Asia.

Most of our associations in the Dinaric Karst have been with the Karst Research Center in Postojna, and to a lesser extent the Karst Institute in Croatia. We have worked with a large number of the staff at Postojna, mainly as editorial advisors to Acta Carsologica (for which Art is on the Advisory Board). We have also participated in several of the international karst programs held there. Art participated in the 2009 karst program held at Plitvice, and is in communication with several Croatian karst scientists. We have also visited many of the karst areas of Bosnia and Crna Gora. We have not specifically collaborated with local scientists on projects in the Dinaric karst.

\section{WORLD KARST AREAS}

Which world karst areas would you particularly emphasize, and why?

Southeastern Asia and Dinaric region for the scale and variety of their karst features, and as the sites of the earliest substantial karst studies. Papua New Guinea and Sarawak for the great scale of their tropical karst features. The Alps-Pyrenees and related chains for their classic alpine karst. The Carpathians and related chains (including Ukraine through Georgia and Turkey) for their great variety and deep caves. Russia for the vast extent and geological variety of its karst. The Apennines of Italy for their spectacular sulfuric acid karst and thermal karst. Central America for its extensive mountainous tropical karst. North America for the variety and extent of its karst regions (including the unique Black Hills karst, with its huge paleokarst-hosted caves; and the nearly unique Guadalupe Mountains with their giant relict sulfuric acid caves). Australia for its vast, strange, and ancient karst areas, such as the Nullarbor Plain. Unfortunately this list cannot do justice to the fact that the scientific importance of a karst area is poorly correlated with its size.

\section{PUBLICATIONS AND POPULARIZATIONS}

I find that most people here in the "classical" karst think that they know everything about karst. In fact, this is a big misunderstanding. How well does karstology address this kind of problem, and how much does it tend to go behind the boundaries of the traditional discipline? How much do karstologists popularize the field? This seems very important, because research budgets sometimes depend on public perception of sciences.
Outreach to the public is vitally important. Toward this goal, in the USA at least, there are many meetings where cavers and karst scientists present information to local groups for educational purposes. In the national park caves (e.g., Carlsbad, Mammoth, Wind, Jewel) as well as many state-owned or privately operated caves, part of the message of tour guides is the importance of caves and karst to water supply and land-use issues. The American Geological Institute has published a booklet, Living with Karst, written by several prominent karst researchers, and aimed at distribution to the public. There is also widespread popular recognition of environmental problems in karst (mainly sinkhole subsidence). Unfortunately these lines of communication are limited by the small amount of time available to scientific researchers and, for the public, by the torrent of largely irrelevant information and the many pressing problems of modernday life that so easily fill one's days.

What should be stressed about karst outside karst circles? What could noticeably demonstrate the importance of karst?

The most pressing thing to communicate to the public is the importance of karst to water supply and land-use problems such as subsidence, and the protection of karst and caves because of their scenic, scientific, and environmental value. See other answers to related questions. Unfortunately the best time to educate the public is immediately following a major disaster.

Public perception of karst depends on a holistic presentation of the field and how it works, in a way that is accessible to the public. How do the USA and other karst regions in the world approach this kind of problem?

All things considered, we think the USA is doing a good job of dealing with karst and presenting it to the public - especially in recent years. Things could be better, but the worst offenses (e.g., toxic waste and contamination of aquifers) seem to be diminishing. In areas of major karst aquifers (Florida, Edwards Aquifer of Texas, etc.) the public is very aware of water-supply issues, thanks to information supplied by regional aquifer management. For example, the Edwards Aquifer Authority and regional watershed authorities in Florida, as well as state and national agencies, communicate well with the local populace and news media.

Living on karst will always lead to problems, especially with the pressures of increasing population, groundwater withdrawal, energy production, and waste disposal. Although most of our federal and state agencies do an adequate and conscientious job, there will always be many more problems than solutions.

Oneonta, New York, USA, November 17, 2010 